\title{
Research on Five Stakeholders \& Five Relationships of Higher Engineering Education in China
}

\author{
Guangshe Jia \\ Economics and Management School of Tongji University, Shanghai,China \\ jiagsh803@yahoo.com.cn \\ Chengbin Xiao \\ Economics and Management School of Tongji University, Shanghai,China \\ cbxiao163@163.com
}

\begin{abstract}
With the development of globalization, higher engineering education has been on the rise which includes five Stakeholders and five relationships. This paper will discuss five relations of higher engineering education: teaching, research and social services, professional education and humanity education, ability education and knowledge education, theoretical teaching and practical teaching, development of education and development of national and regional economy. Among them, teaching, research and social services are three major functions of higher engineering universities; professional education and humanity education, ability education and knowledge education, theoretical teaching and practical teaching are the goals of higher engineering education; development of education and development of national and regional economy involve the interaction between higher engineering universities and society. Furthermore, the five stakeholders are students, teachers, universities, employers and governments. The five relationships and five stakeholders of higher engineering education are reunified firstly, and at the same time, the driving force of various interests of higher engineering education is analyzed thoroughly at the higher level for guiding and enlightening the future development of our country's higher engineering education.
\end{abstract}

Index Terms - higher engineering education, five relationships, five stakeholders, driving force, development

\section{INTRODUCTION}

With the development of the global economy, new trends of cooperation and competition among countries

Manuscript received January 16, 2009; revised June 17, 2009; accepted July 15, 2009. and regions have greatly increased. Facing the rapid varying environments both home and abroad, China, in order to enhance the nation's integrated strength and international competitiveness quickly, has carried out the realization of modernization which is the third step of its goals. With new demands rising, facing this situation, China's higher engineering educators are feeling great pressure of responsibilities. Among them, clarifying five relationships of China's higher engineering education (teaching, research and social services, professional education and humanity education, ability education and knowledge education, theoretical teaching and practical teaching, development of education and development of national and regional economy) is urgent for the national compond target strategy. With decades of development and continuous reforms, a unique and relatively complete system of China's higher engineering training and institutional education has taken shape. On the whole, it lags a little bit behind Western counter-parts and, at the same time confronts the following problems:

(1) Teaching, research and social services

(1) As the jumping-off point of technology is very low, how to enhance the capability of universities and employers to innovate, and to stimulate technological development and encourage its commercialisation and application, to achieve or exceed the advanced technology, and manage to break the strange circle that the conversion rate is not high about achievements in scientific research.

(2) On teaching, research and social services, on condition that the teaching the scientific research can be guaranteed, how to ensure students and teachers to get effective innovation, serving society and enterprises (employers), and to enable the students, the teachers, 
universities and employers to strike a balance in the driving force of various interests.

(2) Professional education and humanity education

How to stimulate the driving force of interests of the teachers, universities and enterprises (employers),so they can cultivate higher engineering graduates with good humanity qualities and professional manners.

(3) Ability education and knowledge education

How to satisfy social requests and at the same time have corresponding abilities and knowledge about adaptation and survival in society for students with the closely collaboration of universities and employers, of course, there is a premise, namely, do not harm the school and employer's benefits.

(4) Theoretical teaching and practical teaching

(1) Teachers become the role of engineers at enterprises (employers) and employers become the teachers at universities, which is advantageous to the school and enterprises. Then how to maintain a stable balance on interests structure or to give equal achievements of rewards when universities and enterprises (employers) face all kinds of differences, particularly differences in profit.

(2) How to keep the sufficient driving force for enterprises (employers), which enterprises (employers) cannot make a profit in a short time from the practical teaching, even if they must bear some losses.

(5) Development of education and development of national and regional economy

At present, Chinese employers lack serious innovation which is based on their own ability, while higher engineering graduates or teachers can create some new businesses, of course small at first, which would be the important force of national economy and regional economy. Then, what measures would be taken to support them by governments, employers and universities?

\section{THE SIGNIFICANCE OF STUDYING CHINA HIGHER ENGINEERING EDUCATION AND FIVE RELATIONSHIPS BASED ON THE INTEREST-DRIVEN}

The target of higher engineering education is cultivating engineering students with the main engineering-related technologies and management capabilities. The development of science and technology requires the development of higher engineering education to keep up, so a kind of situation can be formed that science, technology and engineering can commonly develop. But China higher engineering education is facing its bottlenecks, so it's urgent to solve the problems and actively explore the five relationships and driving force of China's higher engineering education at the national strategic level. But so far, it has not yet sorted out the five relationships and revealed the driving force of interests of the five stakeholders (students, teachers, universities, employers, government). Therefore, it is of great significance to guide national strategies by studying China's higher engineering education and the relationships among driving forces of the five stakeholders, which can specify the whole national development. It is mainly manifested in the following aspects:

(1) The direct purpose of higher engineering education is for students to become useful people, to embark on student's fundamental interests, and to promote the allround development of students and people-oriented programs. Guided by the development strategy, we can achieve a faster and better development of China higher engineering education with the least wear and tear by mobilizing the interests of the five stakeholders.

(2) Economic development is one of the basic national policies, and engineering serves economic development directly. A stable development on higher engineering education is a huge driving force for the national economy.

(3) By identifying the five relationships and mobilizing the driving forces of interests of the five stakeholders fully, there is no doubt that higher engineering education will develop better with maximum benefits and least depletion.

\section{THE MAIN VIEWS AND THEIR EVALUATION OF RECENT RESEARCH ON HIGHER ENGINEERING EDUCATION ABOUT THE FIVE RELATIONSHIPS}

\section{1 the main views of higher engineering education at home and abroad about the five relationships}

In foreign countries the main points are: three helix structure of teaching, research and social services ${ }^{[1]}$; the specialization decreases own influence of humanities ${ }^{[2]}$; knowledge innovation and ability development ${ }^{[3]}$; fundamental research comes from practice, practice topics comes from the fundamental research ${ }^{[4]}$; scientific theory of regional economic development ${ }^{[5]}$, etc.

Government have already made it clear that teaching, research and community services should be combined. Now, there are more and more emphasis on the general education after professional education, the higher engineering education starts to pay more attention to humanity education. Correspondingly, China's higher education of liberal arts' development is to take the liberal arts from the attenuated liberal arts, then develop it vigorously. Since China entered the popularity stage of 
higher education ${ }^{[6]}$, ability education is certain to carry weight. China's higher engineering education has always stressed combining theory with practice, subsequently the research and transforming its achievement causes integrated higher engineering education with the economic development closely. Especially with China's reform, opening policy and the development of market economy, the higher engineering education interactive with the development of national economy and regional economy is becoming more necessary.

\section{2 evaluation on the views of recent study from home and abroad}

Generally speaking, we can find various views of the five relationships which have been all involved, but its strategic height and the depth of researching the problems are more or less insufficient. However, previous discussions were limited to single or multiple relationships; there hasn't been a study that focuses on the five relationships, inevitably neglecting the influence of each stakeholder or the driving force behind them. Also it lacks width and depth on the study of single or multiple relationships. Developing education is all a national's request, is reflection of national willpower, and is to realize the entire national strategy, which demonstrated one kind of national competitive power. The ultimate purpose of education is to cultivate and shape people, and to represent the principles of peopleorientation. Society's basic structure is the family, the family raises the person, but education makes the person socialized, which than integrates the person into the society. At present, in the background of the vigorously developing economy, science is one kind of basic research; technology is one kind of method of solving actual problems, engineering is than an applied process of solving actual problems and it serves the economy directly. Engineering is in the forefront of the societal development and its level of development determines the economic level directly. Looking at it from this angle, engineering students' development and the economical development are decided by higher engineering education materially. Simultaneously, higher engineering education also plays a role of vinculum between them, the five relationships can be rarely studied from this stratification, and rarely face up to the driving force of benefit behind them.

To sum up, we can see that the process of development of foreign higher engineering education is from tradition to modern, develop unceasingly forward in the course of solving the problems that occurred during different times; at home, its development is an imitation fumble process following the foreign steps based on our country situation.

\section{EXPLORATING FIVE RELATIONSHIPS AND DRIVING FORCE OF CHINA HIGHER ENGINEERING EDUCATION}

It should be noted that the rapid and stable development of the national economy benefits the five stakeholders of China's higher engineering education. Government, as the leading role of the national economy, effectively dominates the process of national development and its new strategic view should be more than top the others. At the same time, universities should construct a model to foster higher engineering education personnel so as to meet the need of all aspects of society, in full view of the scarcity and poor commence, not try to train graduates with their own pattern. In other view, it's wise to view cultivating students and employing students on the ideas of customer and market. There's no denying that graduates are the "products" supplied by universities, enterprise (employers) hoped that the "product" can be used, moreover be uses easily. Because the enterprises employers) cut out the massive pre-job training and graduate training time of new recruits, save costs and increase efficiency. In terms of profits, universities and enterprises employers) should cooperate to cultivate the students and their "producers" - teachers. This not only benefits students' career and study, but also it is helpful to their scientific research and the transformation of achievements. Therefore, the interests of the five stakeholders can be integrated, coordinating in the development of national economy and forming a virtuous circle of innovation which universities are the active knowledge and innovation of bodies, enterprise (employers) are technology innovation and market innovation bodies on a more national creative system of the government's leading factor.

\subsection{Relationships of teaching, scientific research and social services}

The relationships of teaching, scientific research and social services, has been set store by many countries as one kind of approach to facilitate a faster transition from research to actual production, impel the combining of the science and technology and economics, so various countries need to take various measure to expand positively. The government should be the policy maker and the coordinated guide on the human chain of teaching and scientific research and the industrial chain of social services, and they must build public platforms and interactive environments for teaching, research and social service by related construction. By "the knowledge 
investment, to output of scientific and technical payoffs, arrives at the economical development"[7], bring about the development of teaching, research and social services, format a circular environment of "research of teaching, social services of research, teaching of social services". In the circulation, universities should aim at The personnel market after several years with long-sight, and then lay plans to cultivate students according to the demand. But for the demand, the enterprise (employers) will have more accurate and sensitive foresight, therefore, about cultivating students, universities need and must strengthen the cooperation with enterprise (employers). It is possible that lets involvement in university's scientific research topic, universities (including teachers and students) participate in the technical research and product research and development of enterprise (employers). Simultaneously, the teachers and students capitalizes knowledge in scientific research and social services ,the enterprise (employers) better educated capital (of course, the better educated is to better capitalize).The universities become important support strength for servicing the production of enterprise (employers), at the same time they will gain excellent opportunities of development and greater momentum of development. Also, enterprise (employers) can obtain the technology support of experts at universities and know the development trend of technology, which means much to enterprise (employers) in keeping a sustainable development by the strategy of exerting enterprises' competitive advantages. By the cooperation and social services, the universities can stand in the forefront of the technology industry and the highend of development of industry, aim at the future direction of industry, carry out the advanced idea and clear managerial guiding ideology of running universities, which will make universities, the specialty and the trained student has the core of competitiveness. Therefore, the universities should integrate the discipline construction into big circulation of enterprise production, take a series of measures to encourage resources and Platform of research and development open for the enterprise (employers) and society, forms the intercommunicating and common shared mechanism with the employers, then the technological powers of universities will rely and become an important research and development department of enterprise (employers).

Therefore, dealing with this relationship needs dominance of the government, collaboration of employers, coordination of universities, simultaneously there are also participation of students and instruction of teachers. Based on these, teaching, research and social services should be done:
(1) The government, as the dominant player, should consummates the personnel training chain and the industrial innovation chain together with universities and enterprise (employers), and it must raise the investment, perfect mechanism and make it systematized and standardized.

(2) The universities should strengthen the communication with the enterprise (employers) and set up an inquiry board with the participation of related departments of government, which supplies ideas for development and proposes the better strategies of development.

(3) Teaching and scientific research can be developed, scientific research and social services also can be promoted together. On the foundation of maintaining the independence of teachers, a balanced point can be found in teaching, scientific research and social services, and they will become a pioneer in the process of transforming to the innovative universities.

(4) Examinations for achievements of scientific research cannot merely aim at papers, they should at the experimental achievement and assembly experiment, and take them as the assessment criteria which the experimental achievement and the assembly experiment must account for the major proportion of examinations, in this way it can enhance the achievements of conversion rate in scientific research and greatly reduce the superficial behavior on it.

\subsection{Relationships of professional education and humanistic education}

It is an important channel to cultivate national identity of students by humanistic education, and it is an important way to reinforce the nationality cohesion and enhance international contacts. At present, it is a neglectful phenomenon that graduates loose their humanistic morals with China's higher engineering education, they lack good faith, belief in personal interests, and lack professional knowledge, bottom-line spirit of science, the system's habits of mind and the view with internationalization angle. Such "products" are adverse for universities, enterprise (employers) and the whole society. The enterprise (employers) dare not to use them in order to avoid risk, reputation of teachers and university will be damaged, this will affect the employment of university own. And such "product" affects interests of teachers, universities, enterprise (employers) and the government, far more important is that the education opportunity costs on a whole nation is very big and it is a serious waste of educational resources of a nation. Conversely, it is very disadvantageous to the career of students; meanwhile, it will also have an enormous adverse effect to the competitive power of the 
whole country. However, the goal of higher engineering education of a developed country is cultivating students with the global employment competitive power. The government, university and teachers should pay special attention to the professional education and the humanistic education from the sources, the employers should also consider humanity education as specialization stand in a far angle and forms one joint force of benefits with the government, universities and teachers. The modern society is not only a benefit for the community, but also one's ethics community. With adapting to the circumstance of ethics community, China's higher engineering education can cultivate the "product" who can walk in or eagerly anticipates the frontiers of the discipline, can lead team innovation independently, accomplish major technological project independently, and play the role of leader in the profession and industrial field.

Therefore, dealing with this relationship needs advocacy of the government, affection of enterprises (employers), implementation of universities, simultaneously there are also performance of students and instruction of teachers. Based on these, professional education and humanistic education should be done:

(1) The government should be aware of the adverse consequences to the whole country of the professional education is paid importance and the humanity education is ignored, which will lead to the loss of morals of engineering graduates, policy must be taken to advocate the integration of professional education and humanistic education. Universities should enhance the idea of engineering students, improve their humanism and enforce their social responsibility by implement these policies.

(2)The professional education must take employment as the guidance, the purpose of studies is for the application of knowledge and employment, humanity qualities is the necessary and sufficient condition which seeks for employment. Enterprises (employers) must strengthen the influence on training model of universities, assist the universities to draw up the measure, strengthens the engineering ethics moral education.

(3)Teachers' humanism will have the direct influence on the students, therefore teachers' humanistic quality should be inspected firstly, they can study when they teach students, humanistic education of teachers and students must be tied up.

\subsection{Relationships of ability education and knowledge education}

At present, this discipline is often taken as its guidance for China's higher engineering education, there are always many attempts that all knowledge will be pumped into students' brains, but it doesn't take the demand of enterprises (employers) as the guide, complete the curriculum and the cultivating plan with the reference of employers' demands. However, there is neither necessary nor possibility in teaching and studying all knowledge. Even if you have learned total knowledge at present, there would be lots of new knowledge in the future, but students will enjoy a long life when they know how to innovate, establish a business and study independently. For this point, teachers are too easily influenced by the government and policy of universities under their own driving force of interests. Although enterprises (employers) have the immediate interest, just helpless influence, and a weak resound. The government and universities must regard themselves as service organizations, factories, not only their administration structure, they must listen to the "voices and opinions of enterprises (employers), and take them into the rank of training mode makers and formulate rational cultivation policy with their helplessness. Government, universities and enterprises (employers) work out the reasonable training policy together, which the government and universities are driven by the strategies of the overall country and talent development of higher engineering education, and the enterprises (employers) have influence on the government and universities, which is based on the driven force of interests of enterprises (employers) themselves. Furthermore, teachers implement and execute the policy based on the driven force of interests of teachers themselves. Students will get appropriate education virtually with more reasonable policy and training modes, and benefit themselves.

Therefore, dealing with this relationship needs advocacy of the government, affection of enterprises (employers), implement of universities, simultaneously there are also perform of students and instruction of teachers. Based on these, ability education and knowledge education should be done:

(1) Under the initiative of government, universities should contact with the employers closely,understand their demands, the idea should change that they are the supporting organization merely provides the human resources,but be one organization which the innovative inventors in the future will flow in it continually. under the assistance of enterprises(employers), they must adjust the optional course offering, especially free elective courses and interdisciplinary courses, emphasis to be placed on promoting students' ability in loose learning atmosphere and general across education. 
(2)With improving teacher quality, universities and teachers formulate the ability of education and knowledge education, train students' methods of solving questions, mental vitality and exploratory spirit. Students should become the men with independent motion and thinking by cultivating and obtaining the ability to learn, innovate and construct the ideal mansion, not just adherence blindly to the path of others.

\subsection{Relationships of theoretical teaching and practical teaching}

In China's higher engineering education, the main channel of acquiring knowledge is in theory teaching. As it is well known, much knowledge isn't transmited to students in the classroom of higher engineering educational fields, but students have little chance to get part-time jobs related to their profession. Learning the knowledge is similar to the growth rule of animals and plants: the animals and plants act during the daytime, lose the cells, patch the cells at night, metabolize, and then start to grow. In theoretical teaching, leading role are teachers, the students are instilled into the content teachers have told, "loses the cell"; however, in practical teaching stage, leading role are students. Understanding of theoretical knowledge in their practice,” Repair cells” successfully. Education with only theoretical teaching, not practical teaching is similar to a biological plant that only lives during the daytime, the "biological plant" cannot grow healthily. Go furthe, practical teaching's main feature is that it can provide one kind of real environment and chances of independent thinking for students enhance the exchange among teachers, students and engineers. At the same time, students can obtain strengths by their own understanding, communication and realizing their society with much more social practical experiences, and they will integrate the society and adjust to competition very quickly after graduation. Of course, this demands the combination of universities and teachers, and coordination of enterprises (employers). The government should support and guide practical teaching in the policy, make universities, enterprises (employers) and the teachers have the benefit in the identical vector, then students will obtain this vector benefits directly by the "rigid body " formed by universities, enterprises (employers) and teachers. Universities can have enthusiasm and the financial resources of arranging practical teaching, which the government should increase education fund appropriation and subjects. It is possible to implement the partly tax-free policy for enterprises (employers) support the practical teaching, there is benefit enthusiasm for them, and it has the opportunity to know that the front projects in their fields. The teachers participate in practice and teaching with more subsidies and can realize opportunities of topic, and can obtain first. Therefore, the government should grasp the direction of the force, and let universities, teachers and enterprises (employers) be in the same force vector, then students' interests are distinguished.

Therefore, dealing with this relationship needs advocacy of the government, instruction of employers, and support from universities. Simultaneously, there are also student guidance and teachers. Based on these, theoretical teaching and practical teaching should be done:

(1) By the impetus of the government and universities, the new personnel training pattern can be established, teaching system can be reformed, practical teaching can be inserted into theoretical teaching scientifically, and the new pattern, theoretical study - practical study - research and summary can be formed.

(2) Given these situations of poor hands, poor creativity from students, the enterprises (employers) establish and provide the combining of site and of connection between theory and practice for the students, and cultivate the students' abilities during the teaching reform practice.

(3) The idea of education must be changed; the purpose of higher engineering education is cultivating an engineer, but not the big literary giant, or big scientist. Teachers must lodge practical teaching into theoretical teaching, teachers can study teaching, and students can study in making and gaining ability by practical teaching under the wide aperture and thick foundation. Simultaneously, teachers must let the students understand that the theory is "source", and the practice "base".

(4) Universities should advocate that some teachers have the title of engineer, at some extent, some teachers should be engineers of definte employers by certain proportions. Higher engineering education cannot be separated from employment, or carrying on the type of education of closed doors. Enterprises (employers) participate in the process of cultivating students, in turn this can promote the scientific research and social services.

\subsection{Relationships of development of education and development of national and regional economy}

There is nothing to say that China's higher engineering universities have an indelible function for China's development of it's national economy and development of regional economy. Since many higher engineering universities, which belong to Central Ministries previously, handed them over to the local government, the local higher engineering education began to develop rapidly with momentum moving from up to down; it has 
been the basic mission for education to serve the development of it's regional economy. As the dominant player, the government should provide the financial support and the policy support for the higher engineering academies. Universities should broaden contributions to the development of the national economy and the regional economy. China's higher engineering education still does not take the market requirement into consideration. Even if it aims at the market requirement, merely embarks on the short-term economic interests and the inspection mechanism, it does not maximize market value of research results. The driving mechanism must be changed. One kind of intrinsic driving mechanism must rise to one kind of value idea; higher engineering education can make great and lasting contributions to the development of the national economy and regional economy. At present, it's emphasis on industrialization for the development of regional economies. This is because, on one hand, there are entire upstream and downstream of industry affiliations, on the other hand, a complete industrial base can have a giant magnetic field effect, which may attract massive outstanding for enterprises and the latent outstanding enterprises to join in this good field domain in search of maximized commercial interests. No doubt, the local higher engineering academies should become the most active element to booster function in developing regional economies. The regional economies developed commendably, matching was appropriate, the entire national economy comes up naturally. But as to the development of entire national economy, it should not pursue industrialization one-sidedly just for industrialization, competition must be permits between the region on the overall situation. But the industrial collision must be prevent, on this point, the government and several key higher engineering academy needs to grasp the overall situation, complete a well-coordinated overall plan, and displays function of engine. The national economy's development and the regional economies development's are the principal aspects of the government economic work, under the boost from university's, it forwards under an impel and association of universities, the enterprises (employers) will be direct beneficiary with higher enthusiasm in this relation. With universities cooperating interactively with the government and enterprises (employers), they may make up great networks of education, and search for new patterns of development. Simultaneously, universities become an important booster strength of enterprise innovation as it develops the economy, and can obtain the extreme opportunities of development and enlarge developmental power. The teacher and students can be involved in this interaction of the economy and industrialize themselves, which is beneficial to sharpen its ability of the open field of vision and deliver achievements in scientific research. However, localization of various stakeholders must be accurated, they cannot be "omission", also they cannot be "offside", bringing into play the respective strong point, seeps mutually, supports mutually, to work according to his ability, or take according to his work interactively. Thus, it may realize "three wins" of universities, development of national economy and regional economies, as well as "three wins" of China's higher engineering education, the industry and the region.

Therefore, dealing with this relationship needs dominance from the government, instruction from enterprises, guidelines from universities, simultaneously there are also the coordination from students and participation from teachers. Based on these, the development of China's higher engineering education and development of national economy and development of regional economy should be done:

(1) Local higher engineering academies cannot only be regarded by region, which is also one of the important component parts and one of the important strategies of China's higher engineering education, so all levels of the government should provide support finance and policy's for higher engineering education and to make contributions to the development of the national economy and regional economies.

(2) Universities should obey the layout of regional education, embark on local conditions and it's own characteristics, makes overall plans, provides the technical support for the enterprises (employers), help its' independent innovation and interactive of mutual benefits. Promoting scientific research by the development of education, higher engineering academies becomes the engine for the development of the national economy and regional economies.

(3) The government should coordinate economic interests between enterprises (employers) and universities, and the universities should coordinate interests with teachers. Higher engineering academies develop with the interaction economical, cultivate creative students, and improve scientific research and the achievements of teachers. At the same time, all the work of universities must avoid interference from the development of the economy, then benefit disputes can be controlled, and the way universities are run can be guaranteed healthily and orderly.

\section{CONCLUSION}


This article stands for country strategies. The five relationships have been explored by analyzing five stakeholders and the driving force of interests behind them. Among them, teaching, research and social services are the three major functions of higher engineering institutions; professional education and humanity education, ability education and knowledge education, theoretical teaching and practical teaching are the goals of higher engineering education; development of education and development of national economy and development of regional economy is interactive with higher engineering institutions and society. In dealing with the five relationships, the government must nationally represent and occupy a dominant position, which must manifest the national will and the request of whole country by developing higher engineering education. Universities and the enterprises (employers) have their own law of development; the schools must manifest their own ideas on education and take cultivate students as its ultimate purpose, which represents the principles of people-orientation. This needs to stimulate teachers' enthusiasm and creativity at the forefront of education, and enable all the five stakeholders to obtain the benefits. Therefore, the driving force of the five stakeholders can be unified and get maximize and join force of vector, promote China's higher engineering education powerfully, enhance China's national competitive power and can make China stronger in the globalized economic development. According to the findings of the study, the table of matrix relationships between five stakeholders and five relationships can be expressed as follows Table 1.

Table 1. Table of matrix relationships of five relationships and five stakeholders

\begin{tabular}{|c|c|c|c|c|c|}
\hline & Students & Teachers & Universities & Employers & Government \\
\hline $\begin{array}{c}\text { Five relationships } \\
\text { teaching , research and social } \\
\text { services }\end{array}$ & participate & guide & collaborate & cooperate & lead \\
\hline $\begin{array}{c}\text { professional education and } \\
\text { humanities education }\end{array}$ & participate & perform & implement & impact & advocate \\
\hline $\begin{array}{c}\text { theoretical teaching and practical } \\
\text { teaching }\end{array}$ & participate & perform & implement & impact & advocate \\
\hline $\begin{array}{c}\text { theoretical teaching and practical } \\
\text { teaching }\end{array}$ & participate & guide & support & guide & advocate \\
\hline $\begin{array}{c}\text { development of education and } \\
\text { development of national and } \\
\text { regional economy }\end{array}$ & participate & participate & guide & collaborate & guide \\
\hline
\end{tabular}

\section{REFERENCES}

[1](United States)Frank H.T.Rhodes, The Creation of the Future: The Role of the American University, translating by Wang Xiaoyang,Tsinghua University Press, Beijing,2007, pp. 196242.

[2](United States)David Ward,Noel Radomski,Proud Traditions and Future challenges: The University of Wisconsin:Madison Celebrates 150 years, translating by Li Manli, Li Yue,Tsinghua University Press, Beijing,2007, pp. 90-106.

[3](United States) Morton Keller, Phyllis Keller,Making Harvard Modern:The Rise of American’s University . translating by Huan Shi, Zhong Zhou, Zhao Lin, Tsinghua University Press, Beijing,2007, pp. 493-550.

[4](United States) Rebecca S.Lowen,Creating the Cold War University: The transformation of Stanford, translating by Ye Fugui,Luo Yan,Tsinghua University Press, Beijing,2007, pp. 147-180.

[5](United States) Henry. Etzkowitz,MIT and the Rise of Entrepreneurial Science, translating, by Sun Yu, Yuan Tao, Tsinghua University Press, Beijing,2007, pp. 143-158.

[6]Wu Qidi. Reform and Development of Engineering education in China. China Higher Education Evaluation, The Shanghai Higher Education Office of Education and Research Institution , Shanghai ,2007,4, P3-7. 
[7]Zhang Renbiao. Interactive of University and City: Analysis of contradictions and countermeasure. Research in Higher Education of Engineering,Wuhan,2008, 3,P11-14.

Guangshe Jia, male, born in 1956, Shandong, China, bachelor degree graduated in 1982 from industrial and civil architecture of Xinjiang Institute of Technology, master degree graduated in 1989 from School of Economics management of Tongji University, doctor degree graduated in 2000 from School of Economics management of Tongji University. His main studying direction is project management, Construction Project Information Management and Large-scale Construction Project Controlling.

He is an Associate Professor of School of Economics management of Tongji University, his main works are as follows: Project Control, Guangshe Jia, Tongji University Press,2003,ISBN7-5608-2541-9/TU•479;Engineering Contract Management ,Guangshe Jia, Tongji University Press ,2005,ISBN7-5608-3042-0/TU.601;study on Largescale Construction Project Controlling model, Guangshe Jia,China Civil Engineering Journal ,2003.

Associate Professor Jia is the member of PMI-Project Management Institute.

Chengbin Xiao, male, born in 1979, Hubei,China,bachelor degree graduated in 2002 from geotechnical engineering major of China University Of Geosciences,master major in School of Economics management of Tongji University. 